\title{
Persepsi Masyarakat Lokal terhadap Keberdaan Situs-Situs Bersejarah dan Ketersediaan Amenitas dalam Pengembangan Wisata Pusat Kota Manado
}

\author{
Natalia Keles ${ }^{1}$, Salsabila A.A. Amir ${ }^{2}$, Merryany T. Bawole*3 \\ Politeknik Negeri Manado-Program Studi D4 Manajemen Perhotelan \\ *Coresponding e-mail: merryany.bawole@polimdo.ac.id
}

\begin{abstract}
The tourism industry is an industry that can provide a multiplayer effect, meaning that it can move all sectors and touch all elements in the structure of society. Tourism as a user of all available sectors, and it will not develop properly when the supply and support sectors are not running as they should. The link between the uniqueness of attractions and amenities such as hotels and restaurants is needed in tourism development, but sometimes it does not synergize well when tourism is developed. The purpose of this study was to examine the local community's perception of the existence of historical sites and amenities in the development of Manado Tua tourism. The method used is descriptive by conducting a survey of 100 respondents who are considered worthy of giving an assessment. The method of analysis is a normal percentage distribution. The results of the study found that in general the existence of historical sites and the availability of amenities such as hotels and restaurants were in good condition and provided positive support in the development of Manado's old city tourism.
\end{abstract}

Key words: local people, historic sites, amenities, tourism development, old city of Manado

\begin{abstract}
ABSTRAK
Industri pariwisata merupakan industri yang dapat memberikan multiplayer effect, artinya dapat menggerakkan semua sektor dan menyentuh semua elemen dalam struktur masyarakat. Pariwisata sebagai pengguna dari semua sektor yang ada, dan tidak akan berkembang dengan baik ketika ketersediaan sektor pendukung tidak berjalan sebagaimana mestinya. Keterkaitan antara keunikan atraksi dan fasilitas seperti hotel dan restoran sangat dibutuhkan dalam pengembangan pariwisata, namun terkadang tidak bersinergi dengan baik ketika pariwisata dikembangkan. Tujuan dari penelitian ini adalah untuk mengkaji persepsi masyarakat lokal terhadap keberadaan situs sejarah dan fasilitasnya dalam pengembangan wisata Manado Tua. Metode yang digunakan adalah deskriptif dengan melakukan survei terhadap 100 responden yang dianggap layak memberikan penilaian. Metode analisis yang digunakan adalah distribusi persentase no
\end{abstract}

rmal. Hasil penelitian menemukan bahwa secara umum keberadaan situs sejarah dan ketersediaan fasilitas seperti hotel dan restoran dalam kondisi baik dan memberikan dukungan positif dalam pengembangan wisata kota tua Manado.

Key words: masyarakat lokal, situs sejarah, amenitas, pengembangan pariwisata, kota tua manado 


\section{PENDAHULUAN}

Industri pariwisata merupakan industry yang dapat memberikan multiplayer effect artinya dapat menggerakkan semua sector dan menyentuh semua elemen yang ada dalam struktur masyarakat. Pariwisata sebagai user dari semua ketersediaan sector secara baik, pariwisata tidak akan berkembangan dengan baik ketika sector-sektor penyedia dan pendukung tidak berjalan sebagai contoh contoh sector perhubungan, wisatawan tidak dapat mencapai daerah yang memiliki daya tarik yang unik, seandainya tidak ada transportasi yang memadai, jalur aksisbilitas yang aman dan sebagainya. Perubahan signifikan yang terjadi saat ini bisa dilihat secara nyata adalah pembangunan infrastruktur jalan / jembatan merata diseluruh pelosok tanah air. Empat hal pokok yang minimal harus dimiliki dalam sebuah bangunan pariwisata yaitu Attraction, Accesibility, Amenitiny dan Ancillary. (4A), yang disebut sebagai supply component of tourism. Atraksi (attraction), Indonesia merupakan negara dengan biodiversity yang tinggi, juga ekosistem terlengkap, semua potensi alam dimiliki di Indonesia, termasuk satu kondisi alam "salju" yang dikejar oleh orang-orang berada di negara tropis untuk melihat langsung. Pada hal kondisi ini ada di wilayah timur Indonesia yaitu Pegunungan Jayawijaya (Papua), namun karena kekurangan informasi serta infrastruktur pendukung yang belum memadai sehingga banyak orang tidak tahu, dan lebih memilik melakukan travelling ke benua eropa dan sekitarnya. Persoalan mendasar yang saat ini diselesaikan oleh pemerintah adalah akses (accessibility), dan suasana keadaan masyarakat (ambience) merupakan hal yang utama dalam pengembangan pariwisata. Sebaik dan sebagus apapun atraksi yang dimiliki ketika, ketika dua komponen tersebut tidak tersedia, maka pariwisata tidak akan berkembang dengan baik dan bahkan cenderung akan ditinggalkan pengunjung. Membahas masalah infrastuktur dan kelengkapan sarana pendukung pariwisata seperti seperti jalan, jembatan, penginapan, tourist information center, fasilitas trakking, serta fasilitas umum memang merupakan sarana yang dibutuhkan dalam daya tarik wisata, hanya saja terkadang untuk mengejar investasi dan permintaan pasar (market demand) sebuah destinasi. Terlepas keunikatan, banyak pandangan umum menyebutkan juga bahwa keunikan bisa diciptakan tak kalah sebuah negeri tidak memiliki sumber daya alam yang memadai, seperti halnya Singapura, yang tidak memiliki keunikan dan sumber daya yang banyak, namun mereka bisa mendatangkan wisatawan dalam jumlah besar dalam setahun. Jadi intinya dalah keterseimbangan antara kompornen pembangun pariwisata harus selalu ada. Kota Manado sebagai ibukota Propinsi Sulawesi Utara, memiliki sejarah yang panjang sehingga membentuk sebuah ibukota, dengan memiliki kultur bangunan dan sejarah panjang, ini menjadikan Manado dapat menjadi destinasi sebagai Kota Tua. Memang Manado tidak seperti Jakarta dan Semarang memiliki begitu banyak bangunan tua jaman colonial, namun setidaknya walaupun kota kecil tetapi tetap saja memiliki sejarah yang membentuk baik secara tangible maupun intangible. Namun dalam pengembangan sebuah bangunan destinasi tidak hanya faktor keunikan, ataupun keunikan bisa dibentuk atau diciptakan, tetapi juga harus didukung dengan ketersediaan sarana dan prasarana yang lain sehingga pariwisata menjadi lengkap. Ketersediaan amenitas seperti hotel dan restoran sangat dibutuhkan apalagi terkait dengan pengembangan wisata kota tua, yang notabene kondisi wisatanya ada di dalam pusat ibukota. Tujuan dari penelitian ini adalah mengkaji persepsi masyarakat lokal terhadap keberdaan situs-situs bersejarah dan amenitas dalam pengembangan wisata kota. 


\section{KAJIAN TEORETIK}

\section{Pariwisata}

Pariwisata menurut Institut of Tourism Society in Britain dalam Pendit (1999) adalah kepergian orang-orang sementara dalam jangka waktu pendek ke tempat-tempat tujuan diluar tempat tinggal dan bekerja sehari-hari serta kegiatan-kegiatan mereka selama berada ditempat-tempat tersebut; ini mencakup bepergian untuk berbagai maksud, termasuk kunjungan seharian atau darmawisata/ekskursi. Hunziker dan Krapft (1942), pariwisata adalah sejumlah hubungan-hubungan dan gejala-gejala yang dihasilkan dari tinggalnya orang-orang asing, asalkan tinggalnya mereka itu tidak menyebabkan timbulnya tempat tinggal serta usaha-usaha yang bersifat sementara atau permanen sebagai usaha mencari pekerjaan penuh. McIntosh dan Gupta (1980) memberikan batasan bahwa pariwisata adalah gabungan gejala dan hubungan yang timbul dari interaksi wisatawan, bisnis, pemerintah serta masyarakat tuan rumah dalam proses menarik dan melayani wisatawan ini serta penunjang lainnya. Spillane (1997) yaitu: harus bersifat sementara, harus bersifat sukarela dalam arti tidak terjadi karena dipaksa, tidak bekerja dengan sifatnya yang menghasilkan upah dan bayaran.

Berbagai definisi diatas dapat disimpulkan bahwa pariwisata adalah kegiatan bepergian oleh orang-orang dari suatu tempat (daerah asal) dengan tidak bermaksud untuk tinggal atau kerja ke tempat tujuan, dan hanya bersifat sementara untuk menghabiskan waktu bersenang-senang(leasure).

Pengembangan pariwisata adalah suatu strategi yang dipergunakan untuk memajukan, memperbaiki, dan meningkatkan kondisi kepariwisataan suatu obyek dan daya tarik wisata sehingga dapat dikunjungi wisatawan serta mampu memberikan manfaat bagi masyarakat disekitar obyek dan daya tarik wisata maupun bagi pemerintah (Paturusi, 2008). Selanjutnya untuk menjadikan suatu kawasan menjadi objek wisata yang berhasil haruslah memperhatikan faktor-faktor sebagai berikut: (1) Faktor kelangkaan (scarcity) yakni: sifat objek/atraksi yang tidak dapat dijumpai di tempat lain, termasuk kelangkaan alami maupun kelangkaan ciptaan. (2) Faktor kealamihan (naturalism) yakni: sifat dari objek/atraksi wisata yang belum tersentuh oleh perubahan akibat perilaku manusia. (3) Faktor keunikan (uniqueness) yakni: sifat objek/atraksi yang memiliki keunggulan komparatif dibanding dengan objek lain yang ada disekitarnya. (4) Faktor pemberdayaan masyarakat (community empowerment). Faktor ini menghimbau agar masyarakat lokal benar-benar dapat diberdayakan dengan keberdayaan suatu objek wisata didaerahnya. (5) Faktor optimalisasi lahan (area optimalization) maksudnya adalah lahan yang dipakai sebagai kawasan wisata digunakan berdasarkan pertimbangan optimalisasi sesuai dengan mekanisme pasar, tanpa melupakan pertimbangan konservasi, preservasi dan proteksi. (6) Faktor pemerataan harus diatur sedemikian rupa sehingga menghasilkan manfaat terbesar untuk kelompok masyarakat.

Dalam pengembangan pariwisata, Page, 1995 dalam Sukarsa, (1999:60-62)

memaparkan terdapat lima pendekatan dalam pengembangan pariwisata yaitu:

1. Boosetern approach, yaitu pendekatan sederhana yang melihat pariwisata sebagai suatu akibat positif untuk suatu tempat dan penghuninya. Namun, masyarakat setempat tidak dilibatkan dalam proses perencanaan dan daya dukung wilayah tidak dipertimbangkan secara matang.

2. The economic industry approach, yaitu pendekatan pengembangan pariwisata yang tujuan ekonominya lebih didahulukan dari tujuan sosial lingkungan serta menjadikan pengalaman pengunjung dan tingkat kepuasan sebagai sasaran utama. 
3. The physical spatial approach. Pendekatan ini didasarkan pada tradisi penggunaan lahan geografis, strategi pengembangan berdasarkan perencanaan melalui prinsip keruangan, spatial. Misalnya pengelompokan pengunjung di satu kawasan dan pemecahan-pemecahan tersebut untuk menghindarkan terjadinya konflik.

4. The community approach, yaitu pendekatan yang lebih menekankan pada pentingnya keterlibatan maksimal dari masyarakat setempat dalam proses pengembangan wisata.

5. Sustainable approach, yaitu pendekatan berkelanjutan dan berkepentingan atas masa depan yang panjang serta atas sumber daya dan efek-efek pembangunan ekonomi pada lingkungan yang mungkin menyebabkan gangguan budaya dan sosial yang memantapkan pola-pola kehidupan dan gaya hidup individual.

Dalam pariwisata yang memahami aspek keberlanjutan, menurut Swarbrooke (1998, 47) menyebutkan keberlanjutan harus terintegrasi pada tiga dimensi yaitu: environment dimension, economic, and social dimension. Selanjutnya berdasarkan konteks pembangunan berkelanjutan, pariwisata berkelanjutan didefinisikan sebagai pembangunan kepariwisataan yang sesuai dengan kebutuhan wisatawan dengan tetap memperhatikan kelestarian (conservation, enviromental dimention), memberi peluang bagi generasi muda untuk memanfaatkan (economic dimention) dan mengembangkannya berdasarkan tatanan social (social dimention) yang telah ada.

Objek dan Daya Tarik Wisata

Pariwisata akan dapat lebih berkembang atau dikembangkan jika suatu daerah terdapat lebih dari satu jenis objek dan daya tarik wisata. Berdasarkan Undang-Undang Republik Indonesia Nomor 10 tahun 2009 Tentang Kepariwisataan, daya tarik wisata adalah segala sesuatu yang memiliki keunikan, keindahan dan nilai yang berupa keanekaragaman kekayaan alam, budaya dan hasil buatan manusia yang menjadi sasaran atau tujuan kunjungan wisatawan. Menurut Yoeti (2006: 167) secara garis besar ada empat kelompok yang merupakan daya tarik bagi wisatawan datang pada suatu negara daerah tujuan wisata tertentu yaitu:

a. Natural Attraction, termasuk dalam kelompok ini adalah pemandangan (landscape), pemandangan laut (seascape), pantai (beaches) danau (lakes), air terjun (waterfall), kebun raya (national park), agrowisata (agrotourism), gunung berapi (volcanos), termasuk pula flora dan fauna.

b. Build attraction, termasuk dalam kelompok ini antara lain bangunan dengan arsitektur yang menarik, seperti rumah adat, dan termasuk bangunan kuno dan modern seperti Opera Building (Sydney), WTC (New York), Forbiden City (China), atau Big Ben (London), TMII (Taman Mini Indonesia Indah) dan daya tarik buatan lainnya.

c. Cultural Attraction, dalam kelompok ini termasuk diantaranya peninggalan sejarah (historical building), cerita-cerita rakyat (folklore), kesenian tradisional (traditional dances), museum, upacara keagamaan, festival kesenian dan semacamnya.

d. Social Attraction, yang termasuk kelompok ini adalah tata cara hidup suatu masyarakat (the way of life), ragam bahasa (languages), upacara perkawinan, potong gigi, khitanan atau turun mandi dan kegiatan sosial lainnya.

Menurut Cooper (1993) unsur-unsur yang menentukan keberhasilan sebagai daerah tujuan wisata adalah: (a). Atraksi wisata (Attraction) yang meliputi atraksi alam dan buatan; (b). Kemudahan untuk mencapai akses (access) seperti ketersediaan transportasi lokal baik darat, laut maupun udara beserta sarana dan prasarana pendukungnya; (c). Kenyamanan (amenities) seperti kualitas akomodasi, ketersediaan restoran, jasa 
keuangan, keamanan serta jasa pendukung; (d). Jasa pendukung yang disediakan oleh pemerintah maupun swasta (ancilary service) termasuk didalamnya peraturan / perundang-undangan tentang kepariwisataan. Dari beberapa konsep pariwisata tersebut maka disampaikan bahwa supply ketersediaan komponen pembentuk destinasi wisata sangat dibutuhkan dalam pengembangan pariwisata (Towoliu \& Takaendengan, 2015).

\section{Amenitas}

Amenity atau fasilitas merupakan segala macam sarana dan prasarana pendukung selama wisatawan berada di daerah tujuan wisata, meliputi kebutuhan akomodasi, penyediaan makanan dan minuman, gedung pertunjukan, tempat hiburan (entertainment), dan tempat perbelanjaan. Fasilitas bukan merupakan daya tarik bagi wisatawan, namun menjadi syarat yang menentukan durasi tinggal wisatawan dan kekurangan fasilitas akan menjadikan wisatawan menghindari destinasi tertentu, (Sugiama, 2011).

Penginapan juga merupakan fasilitas pendukung penting pada suatu destinasi wisata. Penginapan dapat ditemukan di mana pun wisatawan bepergian karena wisatawan membutuhkan lokasi beristirahat dan bersantai selama melakukan perjalanan sehingga dibutuhkan bangunan yang dapat sebagai tempat tinggal sementara atau penginapan. mengartikan penginapan sebagai subsektor terbesar dan paling umum di dalam bisnis pariwisata. Industri penginapan telah menyaksikan inovasiinovasi reguler yang telah menghasilkan berbagai macam diversifikasi produk dalam ukuran, jenis dan layanan yang diberikan, (Pizam, dkk,1978; dan Robustin, 2018).

Dan sector amenitas juga memegang peranan penting dalam perencanaan pengembangan pariwisata.

\section{Persepsi}

Proses individu dalam menginterpretasikan, mengorganisasikan, memberi makna terhadap stimulus yang berasal dari lingkungan di mana individu itu berada yang merupakan hasil dari proses belajar dan pengalaman (Asrori, 2009). Kemudian Slameto (2010) menjelaskan dari persepsi tersebut manusia senantiasa berhubungan dengan lingkungan sekitarnya. Selanjutnya (Walgito, didalam Sulistyani, 2020) menyebutkan bahwa untuk memenuhi sebuah persepsi diperlukan: (1) objek (2) alat indera/reseptor; dan (3) perhatian. Kemudian dilanjutkan bahwa persepsi dipengaruhi faktor, psikologis individu dari pelaku persepsi. Persepsi juga melalui beberapa tahapan antara lain: (1) rangsangan dari objek oleh indera/reseptor, kemudian (2) diteruskan ke otak oleh syaraf sensoris dan (3) otak mengolah persepsi tersebut, diinterpretasi, dan diberikan respons ke individu menjadi menyadari tentang apa yang diterimanya. Sedangkan Toha (2003) menjelaskan bahwa persepsi dipengaruhi oleh faktor interal individu seperti perasaan, sikap, kepribadian, keinginan, prasangka, harapan, perhatian, proses belajar, keadaan fisik, gangguan kejiwaan, nilai, kebutuhan, minat, motivasi; dan 2) faktor eksternal, berupa latar belakang keluarga, informasi yang diperoleh, pengetahuan dan kebutuhan sekitar, intensitas, ukuran, keberlawanan, pengulangan gerak, hal-hal baru dan ketidak asingan terhadap objek.

Dengan demikian berdasarkan konsep tersebut dihubungkan pesepsi masyarakat local terhadap situs bersejarah dan ketersediaan amenitas yang dilihat responden terhadap lingkungan sekitar yaitu situs-situs bersejarah, bagaimana perspektif perspektif mereka menilai fasilitas pendukung dan keberadaan situs bersejarah yang ada dikota Manado 


\section{Perkembangan Objek Wisata di Kota Manado}

Perkembangan kota secara langsung berpengaruh juga terhadap daya tarik wisata, karena keunikan objek wisata tidak cukup mempengaruhi wisatawan untuk berkunjung wisata tanpa ada fasilitas infrastruktur pendukung wisata. Tangian, membagi perkembangan daya tarik wisata di kota Manado menjadi empat bagian yaitu: (1) Potensi obyek dan daya tarik wisata alam seperti: Pulau Bunaken, Siladen, Manado Tua, Pantai Malalayang, Air Terjun Kima, dan Gunung Tumpa, (2) Potensi obyek dan daya tarik wisata sejarah seperti: gereja sentrum (oude kerk), veld box, gua jepang, meriam kuno, batu kuangang, batu buaya, batu banti, parigi tujuh, waruga dotu lolong lasut, batu sumanti, parigi tujuh parigi putri dan klenteng ban hing kiong. (3) Potensi objek dan daya tarik wisata buatan seperti: teater terbuka taman kesatuan bangsa (tkb), museum negeri manado, monumen gugurnya tentara jepang, patung batalyon worang, patung dr. sam ratulangi, patung toar lumimuut, patung wolter monginsidi, patung maria walanda maramis, patung w.r mongisidi dan piere tendean, dan kawasan bisnis boulevard, (4) Potensi objek wisata seni dan budaya seperti: atraksi budaya bantik, tari kabasaran, tari maengket, musik kulintang, perayaan tulude dsb. Sedangkan khusus untuk objek wisata sejarah, terdapat 46 situs sejarah yang ada di Kota Manado, namun tinggal dua objek dalam keadaan terpelihara secara baik dan senantiasa terdapat aktivitas wisata yaitu Klenteng Ban Hing Kiong dan Gereja Tua Centrum, (Permana. dkk, 2020).

Dengan demikian terlihat dari sekian potensi wisata, bahwa daya tarik wisata sejarah tidak begitu diminati, dan kurang mendapat perhatian untuk dikelola secara baik.

\section{METODE}

Berdasarkan permasalahan yang dirumuskan maka pendekatan yang digunakan dalam penelitian ini adalah deskriptif kualitatif, yang divisualisaksin dalam persentasi jawaban responden. Pengambilan sampel menggunakan tehnik purposive sampling yaitu sampel bertujuan pertama dengan pertimbangan waktu penelitian, kedua subjek dinggap mengerti dan paham akan tujuan dari penelitian. Jumlah responden sebanyak 100 responden dengan menggunakan metode survey dan alat instrument berupa kuisioner. Perwakilan responden dianggap merata dari berbagai unsur masyarakat yang ada di kota Manado. Definisi operasional variable terkait dengan atraksi dan amenitas yaitu kondisi keberdaan situs dikaikan dengan ketersediaan hotel dan restoran yang ada di kota Manado. Metode Analisis Data yaitu dengan metode diskriptif interpretatif, dengan alat ukur yang digunakan untuk menganalisis data yaitu Skala Likert. Untuk mempermudah dalam menganalisis secara kuantitatif maka setiap pertanyaan yang ada diberi skor. Berikut skor jawaban atas setiap pertanyaan/pernyataan; "sangat setuju" diberi skor 5, "setuju" diberi skor 4, "netral/ragu-ragu" diberi skor 3, "tidak setuju" diberi skor 2 dan "sangat tidak "setuju" diberi skor 1. 


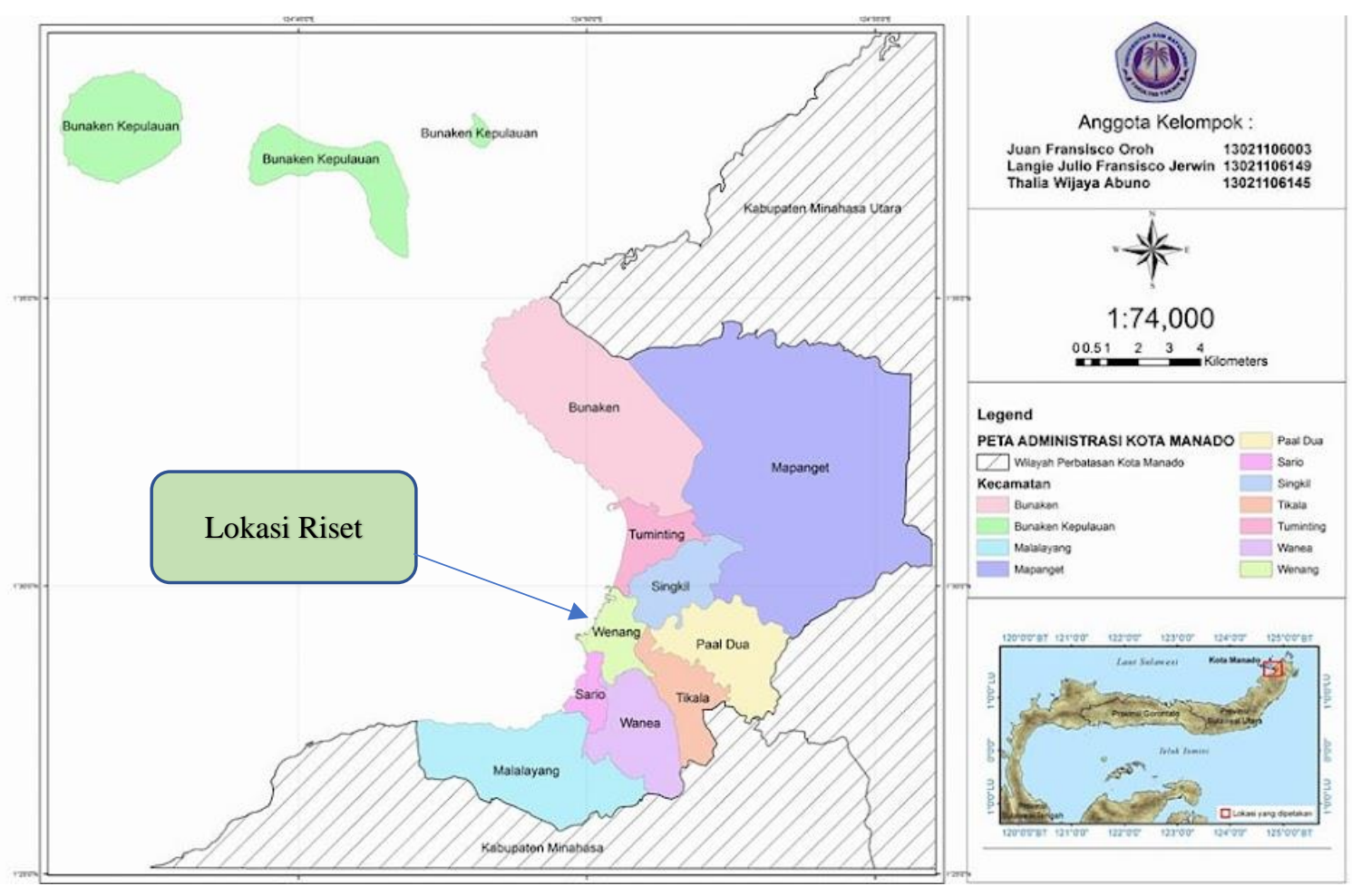

Gambar 1. Lokasi Penelitian

Sumber: http://thaliawijaya-unsrat.blogspot.com/

Pusat kota Manado dimana yang menjadi area penelitian berada di Kecamatan Wenang (Gambar 1)

\section{HASIL DAN PEMBAHASAN}

Berikut ini hasil survey terhadap 100 responden yang mewakili warga Manado, Antara (2009) menyatakan bahwa besarnya sample ditentukan oleh pertimbangan informasi. Informasi yang dimaksudkan adalah menyangkut gambaran kondisi amenitas (hotel dan restoran) dan kondisi kota tua Manado dijadikan sebagai heritage tourism. dilakukan.

Gambaran profil responden sebagai berikut berdasarkan hasil survey yang sudah

Tabel 1. Profil Responden

\begin{tabular}{|l|l|c|c|}
\hline \multicolumn{1}{|c|}{ Respondent } & \multicolumn{1}{|c|}{ Variable $(\mathrm{n}=100)$} & Number & Per cent \\
\hline Jenis Kelamin & Laki-laki & 57 & 57.0 \\
\hline & Perempuan & 43 & 43.0 \\
\hline Usia & $15-20$ & 48 & 48.0 \\
\hline & $21-30$ & 17 & 17.0 \\
\hline & $31-40$ & 21 & 21.0 \\
\hline & $>41$ & 14 & 14.0 \\
\hline Pendidikan & SMA Sederajat & 35 & 35.0 \\
\hline & Perguruan Tinggi & 65 & 65.0 \\
\hline Pekerjaan & Swasta & 17 & 17.0 \\
\hline
\end{tabular}




\begin{tabular}{|l|l|c|c|}
\hline Respondent & \multicolumn{1}{|c|}{ Variable $(\mathrm{n}=100)$} & Number & Per cent \\
\hline & Pekerja Profesi & 6 & 6.0 \\
\hline & PNS & 22 & 22.0 \\
\hline & Siswa & 16 & 16.0 \\
\hline & Mahasiswa & 39 & 39.0 \\
\hline
\end{tabular}

Sumber: data olahan

Berdasarkan tabel 5.2. terlihat bahwa jenis kelamin responden yang dimintai tanggapan, didominasi oleh laki-laki 57\% sedangkan perempuan 43\%. Memang dalam pengambilan data ini tidak ada prioritas atau pun pengumpulan data harus sama $50 \%$ antar jenis kelamin, artinya jenis kelamin tidak mempengaruhi penilaian terhadap pernyataan atau pun pertanyaan yang terdapat dalam kuisioner.

Selanjutnya usia responden sebagai berikut: $15 \mathrm{~s} / \mathrm{d} 20$ tahun sebesar 48\%, $21 \mathrm{~s} / \mathrm{d}$ 30 tahun sebesar 17\%, 31s/d40 tahun sebesar 21\% dan lebih dari 41 tahun 14\%. Usia pun diyakini tidak mempengaruhi responden dalam menjawab pernyataan / pertanyaan yang diberikan. Pada jenjang pendidikan level SMA sederajat sebesar 35\% dan Perguruan Tinggi 65\%. Prosentasi terlihat bahwa level perguruan tinggi lebih besar di banding level sekolah menengah dapat diasumsikan bahwa daya analisis dari responden akan mempengaruhi mereka dalam menjawab pernyataan yang diberikan karena tingkatan pendidikan yang tinggi. Hal ini berarti bahwa responden dari masyarakat terwakili dilihat dari usia dan derajat pendidikan.

Berikutnya status pekerjaan, dimana swasta $17 \%$, pekerja profesi $6 \%$, Pegawai Negeri Sipil (PNS) 22\%, Siswa 16\% dan Mahasiswa 39\%. Dari data tersebut menunjukkan responden yang berstatus profesi sementara menempuh pendidikan total $61 \%$ sedangkan sisanya tersebar sesuai dengan profesi masing-masing yang ada dalam data tersebut. Hal ini berarti bahwa keterwakilan profesi kerja mewakili latar belakang ekonomi, yang kedepan menentukan perkembangan destinasi wisata.

Sedangkan data berikut menunjukkan bagaimana tanggapan responden berdasarkan indicator yang ditanyakan melalu metode survei:

Tabel 2. Tanggapan responden terhadap situs kondisi situs bersejarah dan amenitas (hotel dan restoran) di Kota Manado.

\begin{tabular}{|c|l|c|c|}
\hline No & \multicolumn{1}{|c|}{ Indicator } & Mean & \multicolumn{1}{|c|}{$\mathrm{Sd}$} \\
\hline 1 & Situs-situs bersejarah di Manado unik dan langka & 4.4800 & .50212 \\
\hline 2 & $\begin{array}{l}\text { Situs besejarah di Kota Manado dalam keadaan } \\
\text { terpelihara }\end{array}$ & 4.3300 & .91071 \\
\hline 3 & $\begin{array}{l}\text { Situs situs tersebut bisa memberikan kenangan } \\
\text { (memori) keberadaan kota Manado }\end{array}$ & 4.5000 & .50252 \\
\hline 4 & Situs situs dapat menjadi wisata warisan (heritage) & 4.8600 & .34874 \\
\hline 5 & $\begin{array}{l}\text { Kondisi tempat-tempat penginapan dan restoran } \\
\text { berdekatan dengan situs bersejarah di kota Manado }\end{array}$ & 4.5700 & .49757 \\
\hline 6 & $\begin{array}{l}\text { Keberdaan amenitas mendukung wisata heritage kota } \\
\text { tua manado. }\end{array}$ & 4.7200 & .45126 \\
\hline 7 & $\begin{array}{l}\text { Kondisi keberadaan amenitas tersebar ditempat- } \\
\text { tempat yang strategis di kota Manado }\end{array}$ & 4.6500 & .47937 \\
\hline
\end{tabular}




\begin{tabular}{|c|l|r|r|}
\hline 8 & $\begin{array}{l}\text { Terdapat beberapa amenitas yang memiliki nilai } \\
\text { sejarah yang sama dengan kota tua Manado }\end{array}$ & 4.0600 & .95155 \\
\hline 9 & $\begin{array}{l}\text { Terdapat beberapa amenitas (hotel dan restoran) } \\
\text { memiliki desain historical. }\end{array}$ & 4.1200 & .76910 \\
\hline 10 & $\begin{array}{l}\text { Masyarakat dilibatkan dalam pengembangan wisata } \\
\text { kota tua }\end{array}$ & 3.5800 & 1.12976 \\
\hline 11 & $\begin{array}{l}\text { Masyarakat sekitar paham tentang keberadaan kota } \\
\text { tua dan keberdaan amenitas yang ada. }\end{array}$ & 3.2400 & .71237 \\
\hline 12 & $\begin{array}{l}\text { Akses jalan mudah terkoneksi baik antara situs dengan } \\
\text { amenitas (hotel dan restoran) }\end{array}$ & 3.8100 & 1.01200 \\
\hline 13 & $\begin{array}{l}\text { Kondisi transportasi baik dan mempermudah } \\
\text { menghubungkan dengan lokasi objek wisata dan hotel } \\
\text { dan restoran }\end{array}$ & 4.1400 & .66697 \\
\hline 14 & $\begin{array}{l}\text { Situs bersejarah mudah untuk ditemukan dari setiap } \\
\text { tempat hotel dan restoran. }\end{array}$ & 4.0500 & .82112 \\
\hline
\end{tabular}

Sumber: data olahan, 2021

Berikut ini penjelasan hasil tanggapan responden seperti terlihat pada tabel 5.3., sebagai berikut: Dari pernyataan pertama keunikan dan kelangkaan terlihat responden, menjawab rata-rata menjawab setuju dengan nilai 4.48. Ini membuktikan bahwa responden menilai ada keunikan tersendiri dari berbagai situs peninggalan sejarah yang ada di Kota Manado. Kemudian pernyataan kedua situs bersejarah di kota Manado dalam keadaan terpelihara. Responden menjawab rata-rata setuju dengan nilai 4.3. Memang dari hasil observasi ada beberapa situs bersejarah terlebih yang masuk dalam wisata agama, keadaan terpelihara disebabkan interaksi positif dalam beribadah, sehingga kecenderungan situs bersejarah itu terpelihara dengan baik sebagai contoh: Klenteng Ban Hin Kiong, dan Gereja Centrum Manado, dimana kedua situs tersebut umurnya sudah melebihi 300 tahun lebih, dan masih terpelihara dengan baik. Pernyataan ketiga menyebutkan situs memberikan pengetahuan sejarah keberadaan Manado, terlihat jawaban responden rata-rata setuju dengan nilai 4.50. Dari hasil observasi mendukung jawaban secara positif artinya kehadiran situs bersejarah yang sudah berumur ratusan tahun membuktikan bahwa telah hadir sebuah peradaban masyarakat yang menjadi cikal-bakal terbentuknya kota Manado.

Kemudian pada pernyataan keempat yaitu situs bisa menjadi wisata heritage, tanggapan responden 4.86 setuju dan hampir mendekati sangat setuju. Dari jawaban yang demikian ini bisa diartikan bahwa ada harapan dari responden untuk memaksimalkan situs-situs bersejarah sebagai bagian dari wisata warisan budaya dan sejarah. Pernyataan kelima kondisi tempat-tempat penginapan dan restoran berdekatan dengan situs bersejarah di kota Manado, terlihat rata-rata responden setuju dengan dengan nilai-nilai rata 4.57. Ini menunjukkan saat bahwa secara fakta ada beberapa tempat hotel dan restoran bagian sangat dekat dengan situs bersejarah. Pada pernyataan keenam, keberdaan amenitas mendukung wisata heritage kota tua manado, terlihat jawaban setuju dengan nilai rata-rata 4.72. Bahwa keterkaitan antara atraksi wisata dan amenitas sangat mendukung pengembangan wisata warisan (heritage) kota tua Manado. Selanjutnya pada pernyataan ketujuh yaitu kondisi keberadaan amenitas tersebar ditempat-tempat yang strategis di kota Manado jawaban responden rata-rata setuju dengan nilai 4.65. ini dapat disimpulkan bahwa dapat mempermudah pengembangan wisata heritage dari sisi kekuatan karena pola penyebaran merata dan tidak terfokus pada lokasi tertentu. 
Selanjutnya pada pernyataan kedelapan terdapat beberapa amenitas yang memiliki nilai sejarah yang sama dengan kota tua Manado. Jawaban responden rata-rata setuju dengan nilai 4.06. Memang dari hasil observasi ada amenitas seperti hotel masih terkait dengan lokasi situs kehadiran kota tua manado, contoh Hotel Peninsula dulunya Rumah Sakit Gunung Wenang, masih teringat sekali kehadiran RS tersebut dari jaman colonial, namun sudah berubah hanya tertinggal jalan akses masuk ke hotel yang merupakan jalan setapak yang dibangun sejak jaman colonial dan ini masih terpelihara. Pada pernyataan kesembilan terdapat beberapa amenitas (hotel dan restoran) memiliki desain historical dan rata-rata reponden menjawab setuju dengan nilai 4.12. Artinya beberapa hotel dan restoran memiliki nilai historical, ini sangat perlu dipertahankan dalam konteks pengembangan wisata heritage.

Kemudian pada pernyataan kesepuluh masyarakat dilibatkan dalam pengembangan wisata kota tua, rata-rata jawaban responden netral atau ragu-ragu dengan nilai 3.58. Memang dari tanya-jawab sepintas diakui masyarakat kurang libatkan dalam beberapa program daerah bahkan penjelasan singkat saja untuk Pada pernyataan kesebelas; masyarakat sekitar paham tentang keberadaan kota tua dan keberdaan amenitas yang ada., responden rata-rata menjawab netral (ragu-ragu) dengan nilai ratarata 3.24. Dengan jawaban tersebut terlihat bahwa ada keraguan dari responden bahwa masyarakat mengetahui atau tidak, tentang keberadaan situs dan beberapa amenitas yang terkait dengan situs sejarah, memang dari segi nama tempat mereka tahu, tetapi penjelasan detail tentang keberadaan hal-hal tersebut masyarakat kurang paham. Untuk pernyataan kedua belas, akses jalan mudah terkoneksi baik antara situs dengan amenitas (hotel dan restoran). Jawaban responden umumnya netral (ragu-ragu) dengan nilai 3.81. Memang dari hasil observasi ada beberapa situs akses dan amenitas cukup dekat atau bahkan berjauhan, sehingga pola pengembangan berikutnya adalah dibutuhkan system berupa digital map yang terkoneksi dengan srana transportasi. Jawaban atas pernyataan tersebut memang rata-rata ragu-ragu dengan nilai 3. Dari hasil jawaban responden berfluktuatif artinya ada setuju, ragu dan tidak setuju; jawaban responden cenderung menyebar ini terlihat juga dari nilai standar deviasi menunjukkan angka 1, berarti jawaban responden tersebar dan tidak merata.

Selanjutnya pada pernyataan ketiga belas kondisi transportasi baik dan mempermudah menghubungkan dengan lokasi objek wisata dan hotel dan restoran responden menjawab setuju dengan nilai rata-rata 4.14. Memang dari hasil obervasi menunjukkan rata-rata transportasi dan jalan menuju ke lokasi tergolong aman mempermudah bagi wisatawan berkunjung apalagi nantinya didukung dengan digital map. Pada pernyatan keempat belas, Situs bersejarah mudah untuk ditemukan dari setiap tempat hotel dan restoran. Jawaban responden rata-rata setuju karena memang dari hasil obervasi telah ada tanda-tanda penunjuk arah menuju ke situs bersejarah.

Dari hasil pernyataan yang dilakukan kepada 100 responden dengan jawaban responden yang positif setuju yang walaupu ada tiga pernyataan dengan hasil netral, namun secara keseluruhan jawaban responden baik (setuju), memberikan pemahanan bahwa ketersediaan amenitas dan kondisi daya tarik wisata tua dalam rangka pengembangan wisata kota tua Manado, mendapatkan dukungan positif dari warga local. Hasil penelitian ini juga menunjukkan bahwa responden (warga local) sangat setuju keberadaan situs-situs bersejarah dan ketersediaan amenitas pariwisata perlu mendapatkan pehatian yang serius. Dibeberapa daerah kabupaten kota masyarakat localnya memberikan apresisi yang tinggi bahkan mendukung pengembangan wisata sejarah lokasi mereka berdomisili. Kasus Benteng Moraya di Kabuapten Minahasa 
memberikan bukti nyata dukungan masyarakat khususnya kaum pelajar terhadap revitalisasi daya tarik wisata sejarah di Kota Tondano (Pangemana, dkk, 2021)

Khusus kota Manado juga dukungan terhadap situs dan atraksi sudah terlihat ketika salah satu atraksi budaya china (Cap Go Meh) mendapatkan dukungan yang antusias dari warga Manado dengan menjadikannya sebagai heritage attraction, dukungan sebagai bagian dari wisata pendidikan (Towoliu, dkk, 2020; Permana, dkk, 2020). Pada akhirnya dibutuhkan komitmen dari seluruh stake holder yang berada di kota Manado dalam menara (revitalisasi) seluruh komponen peninggalan sejarah yang ada dikota Manado baik itu bersifat tangible berupa bangunan fisik bahkan intangible berbentuk tarian dan cerita-cerita rakyat dijadikan sebagai daya tarik wisata, mengingat dari ketersediaan infratruktur amenitas dan aksesibilitas kota sudah memadai mengingat kota Manado sebagai ibukota propinsi Sulawesi utara.

\section{SIMPULAN}

Dari hasil penelitian dapat dapat disimpulkan bahwa kondisi ketersediaan tiga unsur pariwisata social-budaya-sejarah dan man-made secara umum terpantau tersedia dengan baik. Ada beberapa memang perlu dijaga dipelihata atau dilindungi dengan aturan perda cagar-budaya. Kemudian dari persepsi responden terhadap situ bersejarah rata-rata responden menaruh persepsi positif terkait memberikan nilai kenangan bagi warga setempat. Untuk ketersediaan amenitas berupa penginapan dan restoran responden menilai hal yang sama, memberikan penilaian yang baik. Berbanding dengan keterlibatan warga dalam hal pengelolaan pengembangan serta pemahaman akan berbagai situs, terlihat responden hanya menilai cukup. Selanjutnya ketersediaan amenitas baik dalam jumlah dan kualitas tersebar secara merata di tiap kecamatan dan ini sangat mendukung pengembangan wisata kota tua Manado. Kemudian dari segi tanggapan masyarakat terhadap ketersediaan atraksi berupa situs objek dalam keadaan baik serta amenita berupa hotel dan restoran mendapatkan dukungan positif dalam rangka mendukung pengembangkan wisata kota Tua Manado.Pemerintah local sebaiknya memberikan perhatian yang serius terhadap berbagai situs bersejarah di kota Manado, disebabkan situs tersebut telah menjadi saksi bagi perkembangan kota, dan kedepan membuka kesempatan bagi pengembangan wisata kota tua.

\section{Ucapan Terima Kasih}

Penulis mengucapkan terima kasih kepada Politeknik Negeri Manado melalui P3M yang berkenan memberikan kesempatan penulis dalam mengikuti hibah PKM untuk mahasswa

\section{DAFTAR RUJUKAN}

Asrori, M. 2009. Psikologi Pembelajaran. Bandung: CV. Wacana Prima.

Cooper, C, et, al, 1993, Tourism: Principles and Practice. London: Pitman Publishing. Pizam, A., Neumann, Y., \& Reichel, A. (1978). Dimentions of tourist satisfaction with a destination area. Annals of tourism Research, 5(3), 314-322.

Robustin, T. P., Andi, R., Suroso, I., \& Yulisetiarini, D. (2018). The contribution of tourist attraction, accessibility and amenities in creating tourist loyalty in Indonesia. J. Bus. Econ. Review, 3(4), 92-98. 
Tangian, D. Pengembangan Produk Interpretasi Wisata Kota Manado Provinsi Sulawesi Utara.

Toha, M. 2003. Perilaku Organisasi: Konsep Dasar dan Aplikasinya. Jakarta: Grafindo Persada.

Hunziker, W dan Krapf. 1942. Grudies der Allgemeinen Fremden Verkehrslehre. Zurich. Switzerland.

Mc Intosch, S dan Gupta. 1980. Tourism, Principles, Practices, Philosophies, Third Edition. Grid Publishing Inc. Ohio.

Paturusi, S. A. 2008. Perencanaan Kawasan Pariwisata. Denpasar: Udayana University Press.

Pendit, N. S. 1999. Ilmu Pariwisata, Sebuah Pengantar Perdana. Jakarta: PT Pradnya Paramita.

Permana, D. E., Towoliu, B. I., Lumettu, A., \& Mandulangi, J. (2020). CAN HISTORICAL SITES IN MANADO BE AN EDUCATIONAL TOURIST ATTRACTION?. International Journal of Humanity Studies (IJHS), 4(1), 88-98.

Slameto. 2010. Belajar dan Faktor-Faktor yang Mempengaruhinya. Jakarta; Rineka Cipta.

Spillane, J. 1997. Ekonomi Pariwisata: Sejarah dan Prospeknya. Jakarta: Kanisius

Sugiama, A. G. (2011, November). Analisis Diskriminan Persepsi Wisatawan Terhadap Kualitas Komponen Kepariwisataan Di Kawasana Wisata Agro. In Prosiding Industrial Research Workshop and National Seminar (Vol. 2, pp. 207-215).

Sukarsa, I M. 1999. Pengantar Pariwisata. Badan Kerjasama Perguruan Tinggi Negeri Indonesia Timur.

Sulistyani, A., Sidiql, R. S. S., \& Yesicha, C. (2020). PERSEPSI MASYARAKAT LOKAL TERHADAP PENGEMBANGAN DESA WISATA BERBASIS ADAT. Jurnal Kebijakan Publik, 11(1), 39-46.

Swarbrooke, J. 1998. Sustainable Tourism Management. London. CABI Publishing.

Towoliu, B. I., Permana, D. E., \& Sangari, F. (2020). Can the Chinese Cultural Attraction Become an Icon of Tourism Cultural Heritage?(A Case in China Village, Manado). Jurnal Ilmiah Peuradeun, 8(3), 601-618.

Towoliu, B. I., \& Takaendengan, M. E. (2015). Perception of tourist towards the potential development of Tumpa Mountain area as integrated ecotourism, Manado, North

Yoety, O. 2006. Pariwisata Budaya, Masalah dan Solusinya. Jakarta: PT Pradnya Paramita 